\title{
The Elements of Contemporary Turkish Composers' Solo Piano Works Used in Piano Education
}

\author{
Sirin A. Demirci ${ }^{1} \&$ Eda Nergiz ${ }^{2}$ \\ ${ }^{1}$ Education Faculty, Music Education Department, Bursa Uludag University, Turkey \\ ${ }^{2}$ State Conservatory Music Department, Giresun University, Turkey \\ Correspondence: Sirin A. Demirci, Education Faculty, Music Education Department, Bursa Uludag University, \\ Turkey. E-mail: akbulut.sirin@gmail.com
}

Received: July 19, $2020 \quad$ Accepted: November 6, $2020 \quad$ Online Published: February 24, 2021

doi:10.5539/ies.v14n3p105

URL: https://doi.org/10.5539/ies.v14n3p105

\begin{abstract}
It is thought that to be successful in piano education it is important to understand how composers composed their solo piano works. In order to understand contemporary music, it is considered that the definition of today's changing music understanding is possible with a closer examination of the ideas of contemporary composers about their artistic productions. For this reason, the qualitative research method was adopted in this study and the data obtained from the semi-structured interviews with 7 Turkish contemporary composers were analyzed by creating codes and themes with "Nvivo11 Qualitative Data Analysis Program". The results obtained are musical elements of currents, styles, techniques, composers and genres that are influenced by contemporary Turkish composers' solo piano works used in piano education. In total, 9 currents like Fluxus and New Complexity, 3 styles like Claudio Monteverdi, 5 techniques like Spectral Music and Polymodality, 5 composers like Karlheinz Stockhausen and Guillaume de Machaut and 9 genres like Turkish Folk Music and Traditional Greek are reached. It is thought that the results will contribute to the field because it will cause a better understanding in the artistic viewpoints of contemporary composers, as well as being a step for the piano and music educators and the students who have studied academic piano education in order for them to be able to understand the contemporary music.
\end{abstract}

Keywords: solo piano works, contemporary Turkish composers, piano education, music currents, music styles, music genres, piano techniques

\section{Introduction}

The technologic developments of the 20th century, the rapid increase in information, the pace in communication-transportation have brought about differences in comparison to the previous century. They have also influenced music as other art branches and constituted the base of the 'contemporary music' concept. The concept that emerged is summarized in Say's Music Dictionary as: "The music of the era that traces to the end of the 19th century. Contemporary music that has followed a haphazard growth is summarized with concepts and terms that arise from its main features: "Modern Music", "Twentieth Century Harmony", Pioneer Music" (Say, 2009).

It is thought that the enriched and various musical materials in the 21 st century have brought about differences in terms of combining these components and establishing the musical idea. This situation constitutes spaces that bring composers together or dissociate them and presents the concept of "currents". In this sense, the main currents and styles in the framework "contemporary music" of were listed by Yöre: "Impressionist Music, Expressionist Music, Electronic Music, Musical Primitivism, Neo-Classical Music, Serial Music, Microtonal Music, Jazz Music, Utility Music, Aleatoric Music, Neo-Romantic Music, Computer Music, Minimal Music, Polystylism Music, New Simplicity, New Complexity, Musical Historicism, Rock Music" (Yöre, 2011).

In this richness of music, it has become more difficult to limit composers with certain currents and styles as in the previous centuries. Therefore the dominant perspective today implies that composers can be considered as individual schools. For example, the German composer, Karlheinz Stockhausen had an impact on many composers who came after him. Danziger explained the resources that are benefitted by the composers who are considered as a school in the musical understanding of the present day Danziger associated individualism that emerge as a result of nationalism to the fact that each composer desire to create his own unique styles in each piece (Danziger, 1991 
as cited in Yöre, 2012).

Apart from the notions of composers and audience, another notion from the developing musical environment is performers. With the major impact of composers, performers have started to use certain components that are not familiar, apart from the traditional methods. Feridun summarized the reflection of this transformation that has started in the last phases of the Romantic Period on the piano as follows: "French Impressionists such as Debussy, Ravel and Satie used... sordino and soft pedal simultaneously and benefitted from the sostenuto pedal that suspends bass sounds for the first time... B. Bartok, Prokofyev, and Stravinsky carried piano to a brand-new dimension by using the piano as a percussion." (Feridunoğlu, 2004). These performance changes that have started to take place at the beginning of the 20th century become more explainable in the 21 st century, in other words, today, and Demirci and Savaş have classified in 10 titles these technical change in the piano performances in general terms (Akbulut Demirci \& Savaş, 2012; Akbulut Demirci, 2010).

In the direction of the given information, the question of how composers, who are creators of the piece, employed contemporary musical components in their works of art formed the main question of this study for the sake of understanding and interpreting the modern-day music in Turkey.

\subsection{Problem Situation}

The main problem of the research study is as follows: "What are the opinions of the composers on adopting musical currents and styles that are called as "new music" in the piano literature?"

\subsection{Purpose}

In the study, it was aimed to identify which currents and styles are preferred among the contemporary music components by the modern-day Turkish composers in the process of creating a solo piano piece.

\subsection{Importance}

As a result of the literature review that was conducted in the framework of the research problem, the studies that address Turkish composers and contemporary music were examined (Barney \& Pleban, 2018; Predoi, 2017; Nayir, 2017; Choi \& Keith, 2016; Coulembier, 2016; Demirel, 2015; Sönmezöz, 2015; McAndrew \& Everett, 2014; Ece, 2006; Ece, 2002). However, it was seen that the studies that identify the musical elements used by contemporary Turkish composers in the solo piano pieces are limited.

It is thought that identifying the musical elements that constitute the philosophical background of the solo piano pieces of the modern-day composers will contribute to the field in terms of understanding the richness and variety of the present-day musical understanding profoundly. Therefore, elements that are used by the composers in the process of creating solo piano pieces were coded and afterwards these codes were associated with specific themes.

It is thought that to be successful in piano education it is important to understand how composers composed their solo piano works.

\section{Materials and Methods}

\subsection{Research Model}

The method of the research was determined as a "Case Study" which is an analytic descriptive research model (Creswell, 2013 as cited in Şahan \& Akbaş, 2017).

In line with the purpose of the study, the data were collected by conducting semi-structured interviews with 7 present-day Turkish composers who are an expert on the subject and analyzed through a content analysis. "The main purpose of the content analysis is to reach concepts and relationships that can explain the collected data. The main process in content analysis is to gather data are similar in the framework of certain concepts and themes and organize and interpret them in a way that the reader can understand" (Çepni, 2012).

\subsection{Study Group}

In accordance with the research problem 103 Turkish composers who are still alive and passed away after the year of 2000 constitute the universe in the direction of the findings obtained through document analysis; and the sample consists of 7 Turkish composers who created pieces in the solo piano literature from the year 2000, who are still alive and accepted to participate in the study. As the study group was shaped in line with the purpose of the research, a composer who is employed in Yildız Teknik University Faculty of Art and Design, a composer who is employed in Dokuz Eylül University State Conservatory, a composer who is not employed in any university, a composer who is employed in Ankara State Conservatory Composition and Conductorship Department, a composer who is employed in Anadolu University State Conservatory, a composer who is employed in Malatya İnönü University State Conservatory and a composer who is employed in İstanbul Bilgi University Music 
Department constitutes the study group of this study.

\subsection{Data Collection Tools}

Data collection was carried out by addressing semi-structured interview question to 7 composers and the question addressed is presented below:

"Which music currents and styles do you find close to yourself among the ones that are called as the "new music" in the piano literature?"

\subsection{Data Collection of Analysis}

Interviews were conducted with the chosen composers through the semi-structured interview question that has been determined according to the problem and qualitative data were collected (Leech \& Onwuegbuzie, 2007 as cited in Polat \& Hiçyılmaz, 2017). The collected data were analyzed by using content analysis (Yıldırım \& Şimşek, 2016 as cited in Polat \& Hiçyylmaz, 2017).

While conducting the content analysis of the data, first of all, the collected data were transcribed. The codes were determined and themes were formed. The results of the related literature were considered in terms of creation of the themes. In the content analysis employed for data collection, the responses of the composers were quoted directly.

Table 1. Interview distribution table

\begin{tabular}{|c|c|c|c|c|}
\hline Composer & Location & Method & Duration & $\begin{array}{c}\text { The Date of the } \\
\text { Interview }\end{array}$ \\
\hline $\begin{array}{c}\text { Alper Maral } \\
\text { (Yıldız Teknik University) }\end{array}$ & $\begin{array}{l}\text { Yıldız Teknik University } \\
\text { Related instructor room }\end{array}$ & Individual & $52^{\prime} 12^{\prime \prime}$ & 29. 03. 2017 \\
\hline $\begin{array}{c}\text { Ebru Güner Canbey } \\
\text { (Dokuz Eylül University) }\end{array}$ & Online & $\begin{array}{c}\text { Contacted by } \\
\text { e-mail }\end{array}$ & & $\begin{array}{l}\text { 17. 03. 2017-31.03. } \\
2017\end{array}$ \\
\hline Hakan Ali Toker & Online & $\begin{array}{c}\text { Contacted by } \\
\text { e-mail }\end{array}$ & & $\begin{array}{c}04.03 .2017-12.03 . \\
2017\end{array}$ \\
\hline $\begin{array}{c}\text { Onur Dülger } \\
\text { (Anadolu University) }\end{array}$ & Online & $\begin{array}{c}\text { Contacted by } \\
\text { e-mail }\end{array}$ & & $\begin{array}{l}\text { 24. 03. 2017- 30. } 09 . \\
2017\end{array}$ \\
\hline $\begin{array}{c}\text { Onur Özmen } \\
\text { (Ankara University) }\end{array}$ & $\begin{array}{c}\text { Hacettepe University Ankara } \\
\text { Devlet } \\
\text { Related instructor room }\end{array}$ & Individual & $58^{\prime} 48^{\prime \prime}$ & 16. 03.2017 \\
\hline $\begin{array}{c}\text { Server Acim } \\
\text { (Malatya Inönü University) }\end{array}$ & Online & $\begin{array}{l}\text { Individual } \\
\text { (video call) }\end{array}$ & $49^{\prime} 33^{\prime \prime}$ & 18.03 .2017 \\
\hline $\begin{array}{c}\text { Tolga Zafer Özdemir } \\
\text { (Istanbul Bilgi University) }\end{array}$ & Online & $\begin{array}{c}\text { Contacted by } \\
\text { e-mail }\end{array}$ & & $\begin{array}{c}24.02 .2017-11.03 .201 \\
7\end{array}$ \\
\hline
\end{tabular}

It was considered to avoid giving guiding examples and directing the participants during the semi-structured interviews. As persuasiveness and transmissibility are essential for providing the validity of the study, the expressions of the participants were given directly and the results were interpreted starting from these opinions. In addition, the data analysis process was explained in detail in order to provide the validity of the research.

In order to provide the reliability of the research, a consistency enquiry was conducted on the composer opinion that was separated into conceptual categories by two experts, a composer-instructor and a component expert on music education. As a result of the enquiry, consensus and differences of opinion were determined and the reliability formula was calculated as $\mathrm{P}$ (Percentage of Consistency) $=\mathrm{Na}$ (Number of items coded in both of the forms) 100/Nt (Total of items in a form) (Çepni, 2012). As a result, the consistency between the assessments of the experts was calculated as 95.23. Due to the fact that this value was above 70, it was accepted that the reliability is provided.

The content analysis of the data obtained from the semi-structured interviews carried out with 7 composers was conducted by NVivo11QualitativeDataAnalysis Program and as a result of this analysis, the codes were obtained and by means of the codes the themes were formed. These themes were identified as currents, styles, techniques, composer and genres that are used by the Turkish composers in their solo piano pieces. 


\section{Findings}

As a result of the semi-structured interviews, 30 codes were obtained from the responses given by the composers and the themes were formed from these codes. In terms of the formation of the themes, 5 elements of the composition process which are "styles", "currents", "genres", "composers" and "techniques" were converted to 5 themes based on the grouping methods of the concepts by the composers. The analysis of the obtained findings conducted by the NVivo11 Program is as follows:

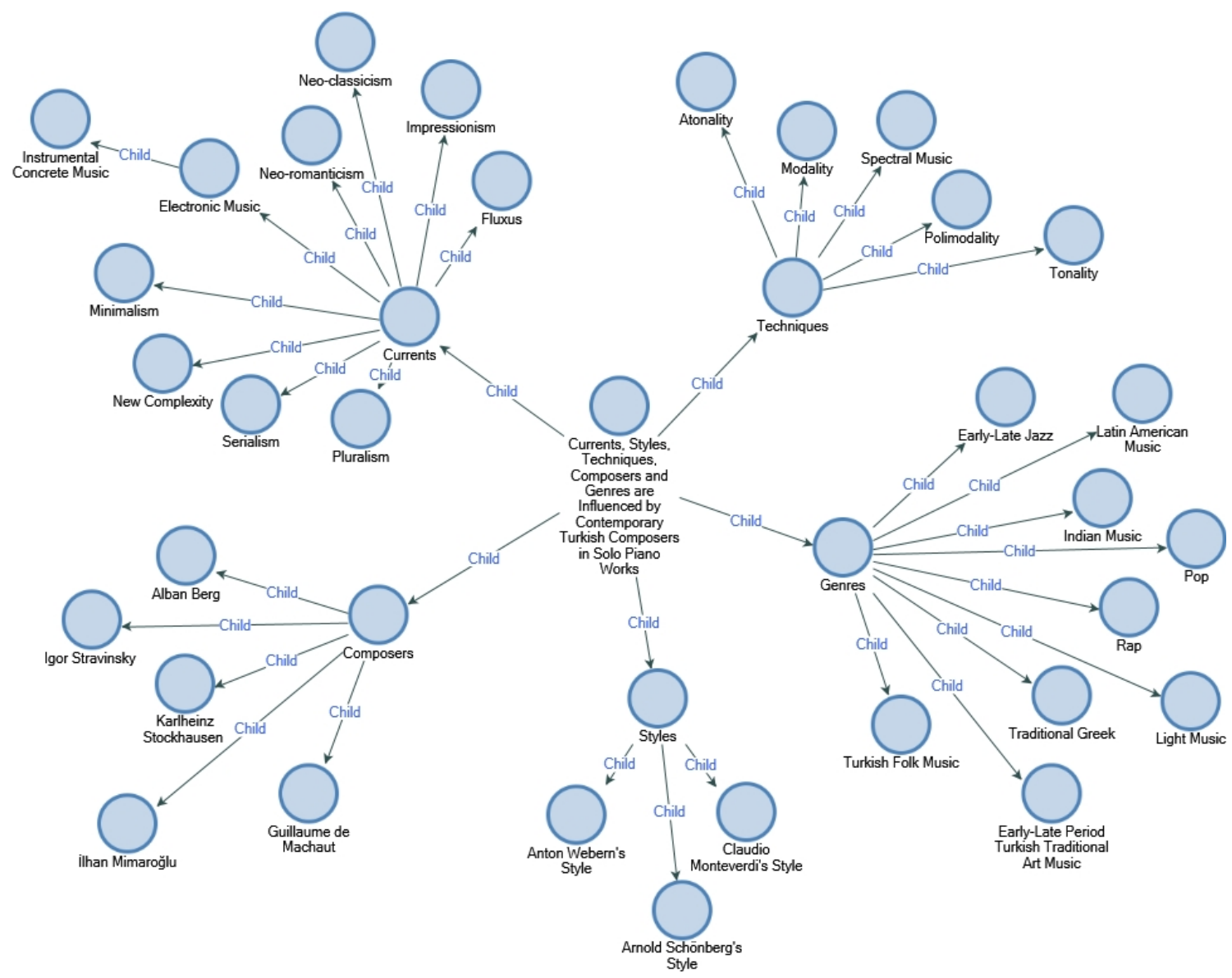

Figure 1. The themes and codes map of the currents, styles, techniques, composers and genres that influenced the present-day Turkish composers (Note 2)

The composer opinions are distributed as follows according to the themes: 


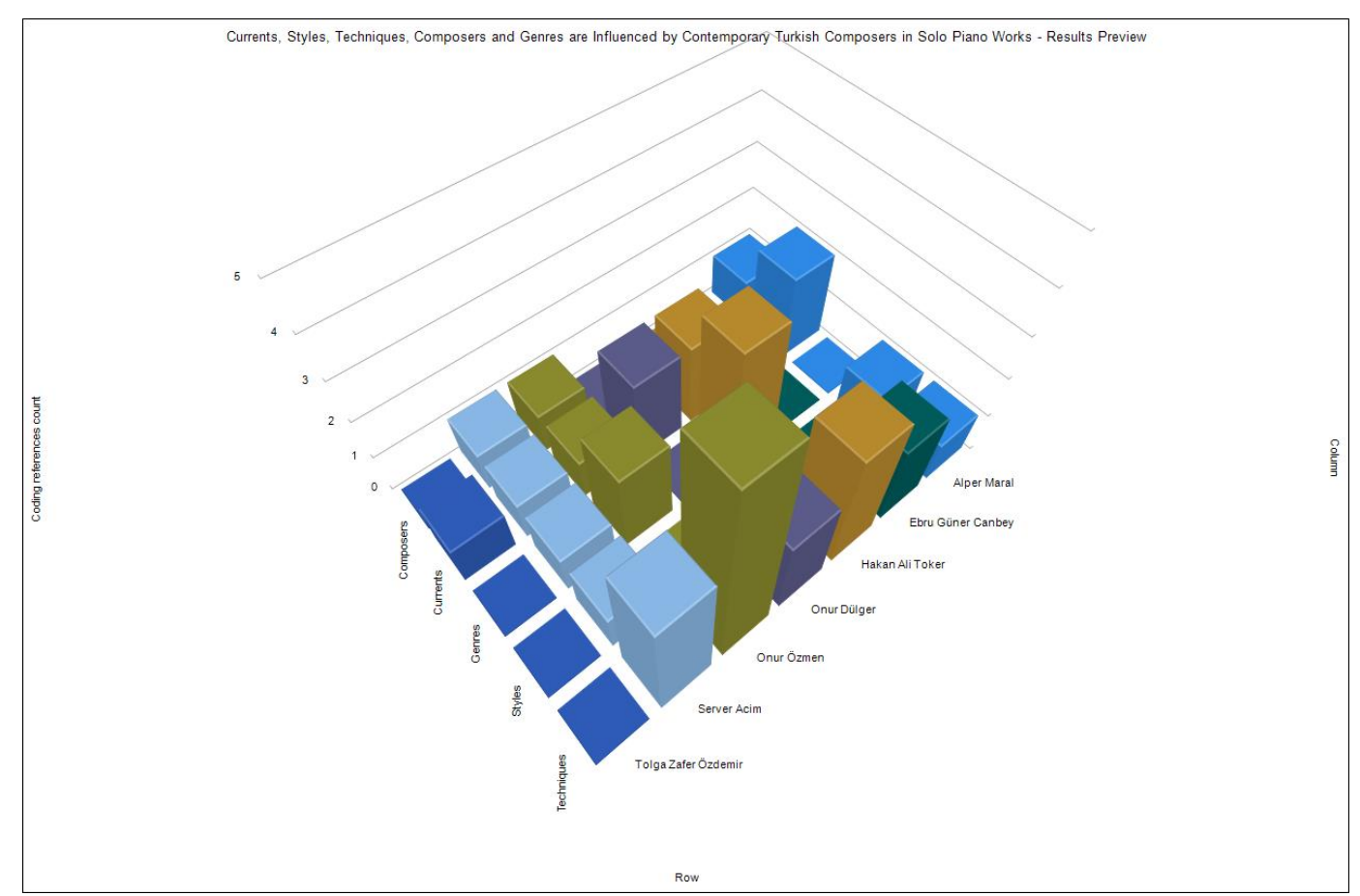

Figure 2. The currents, styles, techniques, composers and genres that influenced the present-day Turkish composers

Each theme which is obtained consists of sub-codes in itself. The codes that belong to the themes and composer opinions are as follows:

\subsection{Currents}

With this theme, the currents composers have been influenced while they are producing their solo piano pieces and other pieces of art. The analysis which was conducted by NVivo11 program is given below. 


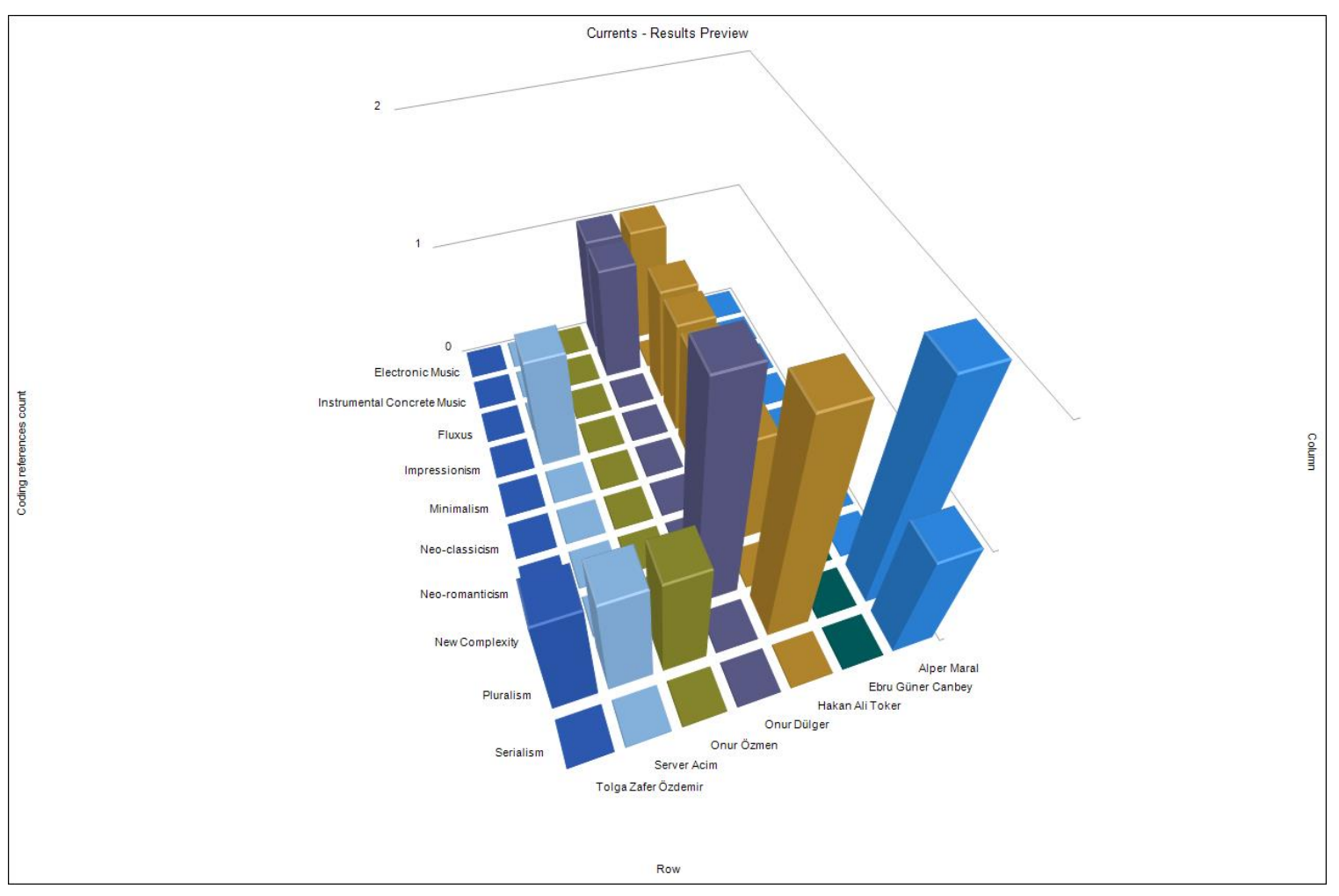

Figure 3. Currents

9 codes that are associated with this theme are presented below with the composer opinions.

\subsubsection{Impressionism}

With this code, the impressionist current that composers were influenced while they are producing their solo piano pieces and other pieces of art was assessed with the opinions of the composers. Impressionism was defined by Say as follows:" The art current that proposes to convey the momentary side of the art that is unrepeatable to the impression that is gained..." (Say, 2009; Aktüze, 2003).

The composer opinions on this code are as follows:

... the pieces that have these characteristics within every current influence me. Among these (If I consider the ones starting from the 20th century) there are many impressionist pieces... (Hakan Ali Toker, interview: 04-12/03/2017).

I can use impressionist chords in 4 measures of the piece. However, this is only relevant in 4 measures, not for the entire piece (Server Acim, interview: 18/03/2017).

\subsubsection{Electronic Music}

With this code, the condition of composers to be influenced from by this current in their solo piano pieces and other pieces was assessed. Sav defines this current as: "The music which is composed by employing the opportunities of electroacoustic (electronic equipment).... It is the orientation of contemporary composers who are in the search of new sounds apart from the sounds of traditional instruments with the rapid development in the technology in this field" (Say, 2009; Kennedy, 1996). One composer shared an opinion on this code:

... the pieces that have these characteristics in every current impress me. Among these (if I consider the ones starting from the 20th century)... there are many avant-garde electronic and electroacoustic pieces (Hakan Ali Toker, interview: 04-12/03/2017).

\subsubsection{Instrumental Concrete Music}

Under this title the opinions of composers on Instrumental Concrete Music which is one of the sources that composers benefit from while they are producing their solo piano pieces. Helmut Lachenmann, who introduced the term explains the term towards his piece, "Pression": "In this sort of piece it is common for sound phenomena to be so refined and organized that they are not so much the results of musical experiences as of their own acoustic 
attributes. Timbres, dynamics and so on arise not of their own volition but as components of a concrete situation characterised by texture, consistency, energy, and resistance..." (Lachenmann, 1970 as cited in Orning, 2012).

In this direction, the composer opinions are as follows:

... In my latest period, the style that I feel close is Instrumental Concrete Music which was named and exemplified by Lachenmann, the following is the sound-oriented style of composers who produce pieces that are the continuation of him ... (Onur Dülger, interview: 24/03/2017, 30/09/2017).

\subsubsection{New Complexity}

With this code the condition of composers to be influenced from New Complexity current which is source that composers benefit from in their solo piano pieces and other pieces was assessed. Yöre explained this current as follows: "It is a technique that emerged as a reaction to the simplicity in music, leaded by Nigel Osborne, include atonal, microtonal, abstract and disharmonic melodies and chords, polyrhythms, non-traditional instrumentalisation, sudden changes in the volume of the sound and accordingly a complex notation" (Ulman, 1994 as cited in Yöre, 2011). In this direction, the opinions of the composers are given below:

New Complexity and Spectral Music are currents that I am interested in and influenced from... (Onur Dülger, interview: 24/03/2017, 30/09/2017).

\subsubsection{Neo-Classicism}

With this code, the condition of composers to be influenced by Neo-Classicism current in their solo piano pieces and other pieces was assessed. This current was defined by Sav as follows: "A current that has started from the 1910s to 1950s in international art music. In Western languages, Neo-classicism includes an understanding that does not want to break its connection with traditions and proposes to re-interpret the values of the past such as "tonal center", "melodic development" and musical ideas towards a purpose (Say, 2009). One composer shared an opinion on this code. The opinion of the composer is presented below.

... the pieces that have these characteristics in every current impress me. Among these (if I consider the ones starting from the 20th century)... there are many neo-classic pieces (Hakan Ali Toker, interview: 04-12/03/2017).

\subsubsection{Neo-Romanticism}

With this code the condition of composers to be influenced by "Neo-Romanticism" current in their solo piano pieces and other pieces was assessed. This current is defined as follows: "It is the composition style of the 20th century. The techniques and characteristics of the Romantic period were represented (19th century) yet it was included in the statement of the 20th century (OnMusic Dictionary, 2017). One composer shared an opinion on this code.

... the pieces that have these characteristics in every current impress me. Among these (if I consider the ones starting from the 20th century)... there are many neo-romantic pieces (Hakan Ali Toker, interview: 04-12/03/2017).

\subsubsection{Minimalism}

With this code, the condition of composers to be influenced from "Minimal Music" current in their solo piano pieces and other pieces was assessed. The current was defined by Say as follows: "The orientation of music that emerge in the USA in the 1960s. Pioneer understanding, Indian music traditions, free jazz and "psychological rock" that employs meditative tendencies. It proposes to use less, limited musical tools (Say, 2009). One composer shared an opinion on this code.

... the pieces that have these characteristics in every current impress me. Among these (if I consider the ones starting from the 20th century)... there are many minimalist pieces (Hakan Ali Toker, interview: 04-12/03/2017).

\subsubsection{Serialism}

With this code, the condition of composers to be influenced by "Serialism" current in their solo piano pieces and other pieces was assessed. The current was defined by Say as follows: The music that is placed according to a serial or an order in a serial and composed by employing sound components or the composition technique that identifies that music: Serial Music. It may include sound component, a pitch of the sound or other values. Serial music includes serials that presents pitches less than 12 as much as it includes 12 tone music (Say, 2009).

In this direction, one composer shared an opinion:

... And sometimes I include different methods, for example, sound compositions that are reached with the opportunities and conditions of Serialism within that pragmatically, if I can assign an appropriate connection 
(Alper Maral, interview: 29/03/2017).

\subsubsection{Fluxus}

With this code, the condition of composers to be influenced by "Fluxus" current in their solo piano pieces and other pieces was assessed. This code was defined by Atakan as follows: "Fluxus artists have become advocates of an alternative approach to art with their works consist of festivals, events, shows, broadcasts, and films. In addition to the ideas coalesce with "Surrealism" and "Dada" they have also influenced from John Cage." (Atakan, 2015).

The composers who shared an opinion and their opinions are presented below.

... the pieces that have these characteristics in every current impress me. Among these (if I consider the ones starting from the 20th century)... there are many Fluxus pieces (Hakan Ali Toker, interview: 04-12/03/2017).

\subsubsection{Pluralism}

With this code, the situation of composers' condition of preferring to compose and produce each solo piano piece and other pieces with a different current-style and technique; and also the situation of composers being influenced from multiple currents, write in multiple styles and use multiple techniques. Pluralism is defined as "the opinion that advocates the existence of many opinions that are equal in social life and irreducible to each other, spaces and forms of reality (Turk Dil Kurumu (Turkish Language Instution) [TDK], 2017). In this direction, the composer opinions are given below:

... I was interested in almost all of them. I have had attempts in most of it yet I say textualism, in other words, say I ground on a more independent edition starting from actual sounds and sound patterns instead of using the issues as tonality pantonality, atonality, modality. Sometimes it may stay close to the "Moment-Form" understanding of Karlheinz Stockhausen. And sometimes I include different methods, for example, sound compositions that are reached with the opportunities and conditions of Serialism within that pragmatically, if I can assign an appropriate connection... (Alper Maral, interview: 29/03/2017).

... the pieces that have these characteristics in every current impress me. Among these (if I consider the ones starting from the 20th century)... there are many pieces which were written with the impressionist, free atonal or 12-tone system, Fluxus, avant-garde, electronic, electroacoustic, neoromantic, neoclassic, minimalist, and the ones with and without national characteristic... (Hakan Ali Toker, interview: 04-12/03/2017).

... Also the music I present as a result might show similarities with the styles in currents that other composers belong to yet I cannot say that "I belong to this or that current. As a composer, I have made many trials as a composer... (Onur Özmen, interview: 16/03/2017).

... It would be right if I say that I use styles in a mixed way. It includes atonality, impressionism and colors from the Kemal Ilerici harmony. I would be more accurate if I would explain it as a mixed use. So there is no such a thing as I feel more comfortable in this or that style. I take a set of flavors from all styles and share them in the piece (Server Acim, interview: 18/03/2017).

...I have been in connection with different music genres until now yet when I compose, I prefer to use them as a color in a palette. For this reason, it is very difficult for me to label it with only one (Tolga Zafer Özdemir, interview: 24/02/2017, 11/03/2017).

\subsection{Composers}

With this theme, the composers have been influenced while they are producing their solo piano pieces and other pieces of art. In this direction, this theme was constituted from 5 codes. The analysis which was conducted by NVivo11 program is given below. 


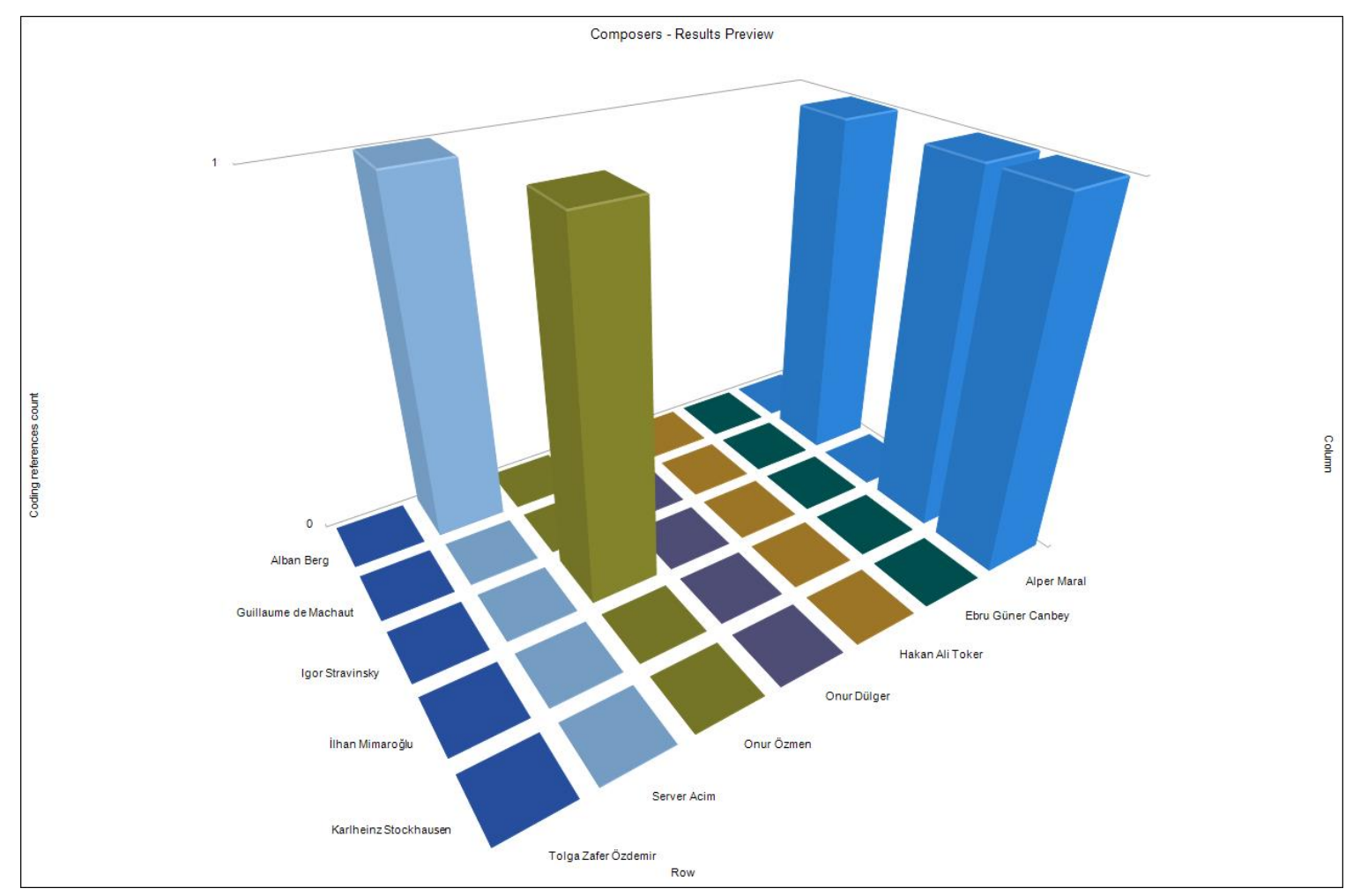

Figure 4. Composers

The identified codes and composer answers are presented below:

\subsection{1 İlhan Mimaroğlu}

With this style, the condition of composers to be influenced by İlhan Mimaroğlu while they are producing their solo piano pieces and other pieces was assessed. The composing understanding of İlhan Mimaroğlu is as follows:

The composer who was born in 1962 was against to inspire from Turkish folk music and divan music, on the contrary to the polyphonic composers generation. He explained the reason for choosing atonal writing as the writing technique as "following the styles that are brought along with connotations" ... As he finds parallelism between composing electronic music and filmmaking, in the framework of this analogy, most of his pieces involved components of acting (İlyasoğlu, 2007).

The composer who shared an opinion is presented below:

... Of course, there are composers who I find close to myself and take as an example... Such as IIlhan Mimaroğlu. However, I should say that I ground on their stances, not what they have done, and I also ground on making a similar move in my environment/context as what they have done in their own context (Alper Maral, interview: 29/03/2017).

\subsubsection{Igor Stravinsky}

With this code, the condition of composers to be influenced by Igor Stravinski's style while they are producing their solo piano pieces and other pieces was assessed. The composer was defined by Say defined it as follows:

One of the most talented composers of the 20th century İgor Stravinski (1882-1971), is a son of a singing artist who was working in Petersburg Opera. The creativity of Stravinski can be separated into three periods:1) The period that lasted until 1920 that he benefitted from the Russian music. 2) The Neo-Classical period between the years 1920 and 1950.3) The period that he worked non-tonal between the years of 1950 and $1971 \ldots$ The harmony he used was based on "modal" or "multi-tonal" techniques yet at the end it is tonal. (Say, 2010a).

One composer shared an opinion on this code:

... Indeed Op. 2298 is a music that I used free atonality and enigmatic serial in the middle and the music that I can describe as under the influence of Stravinsky in terms of colors (Onur Özmen, interview: 16/03/2017). 


\subsubsection{Alban Berg}

With this code the condition of composers to be influenced from Alban Berg while they are producing their solo piano pieces and other pieces assessed. The composer Say defined it as follows: “... Alban Berg gave a more sincere mood to the music with his sensitive and polite character; he is a withdrawn composer of expressionism (Say, 2010a). “... It is seen that Berg wants to establish a connection between atonal and tonal music and to adapt the serial structure to the requirements of tonal music." (Mimaroğlu, 1990 as cited in Say, 2010a).On this code, one composer shared an opinion.

From time to time we hear some parts of the music, let's say through 10 measure or 12 measure, like in the manner of "Twelve Tone" technique ... We hear 12 measure in a structure that is similar to Alban Berg music (Server Acim, interview: 18/03/2017).

\subsubsection{Karlheinz Stockhausen}

With this code, the condition of composers to be influenced by Karlheinz Stockhausen while they are producing their solo piano pieces and other pieces was assessed. The composer was explained by Say follows:

Karlheinz Stockhausen who was born in 1928 in a pioneer representative of "electronic music" ... Stockhausen's discoveries in the scope of new concerts styles propose making music in houses, museums and various spaces ... Stockhausen who put an effort to associate electronic music with a musical method in the years of 1965-1966 inclined to express the "essence of the matter in the universe (Say, 2010a).

The composer who shared an opinion is presented below:

... Of course there are composers who I find close to myself and take as an example ... Such as Karlheinz Stockhausen ... However, I should say that I ground on their stances, not what they have done, and I also ground on making a similar move in my environment/context as what they have done in their own context (Alper Maral, interview: 29/03/2017).

\subsubsection{Guillaume de Machaut}

With this code, the condition of composers to be influenced by Guillaume de Machaut while they are producing their solo piano pieces and other pieces were assessed. The composer was described by Say follows:

Guillaume de Machaut developed the isorhythmic technique. The French ecclesiastics, bard and composer Machaut was born in the region of Champagne around the year 1300 and died in 1377. Machaut gained reputation by composing "ballades", "rondeaux", "chanson", "chansons ballades", "virelais" and chamber. He also wrote many "Motet" and a successful "Missa" (Say, 2010a).

On this code, there is one composer who shared an opinion.

... Of course, there are composers who I find close to myself and take as an example ... Such as Guillaume de Machaut ... However, I should say that I ground on their stances, not what they have done, and I also ground on making a similar move in my environment/context as what they have done in their own context (Alper Maral, interview: 29/03/2017).

\subsection{Styles}

With this theme, the styles of the composers have been influenced while they are producing their solo piano pieces and other pieces of art. In this direction, this theme was constituted with 3 codes. The analysis of the theme that was conducted by NVivo11 program is given below. 


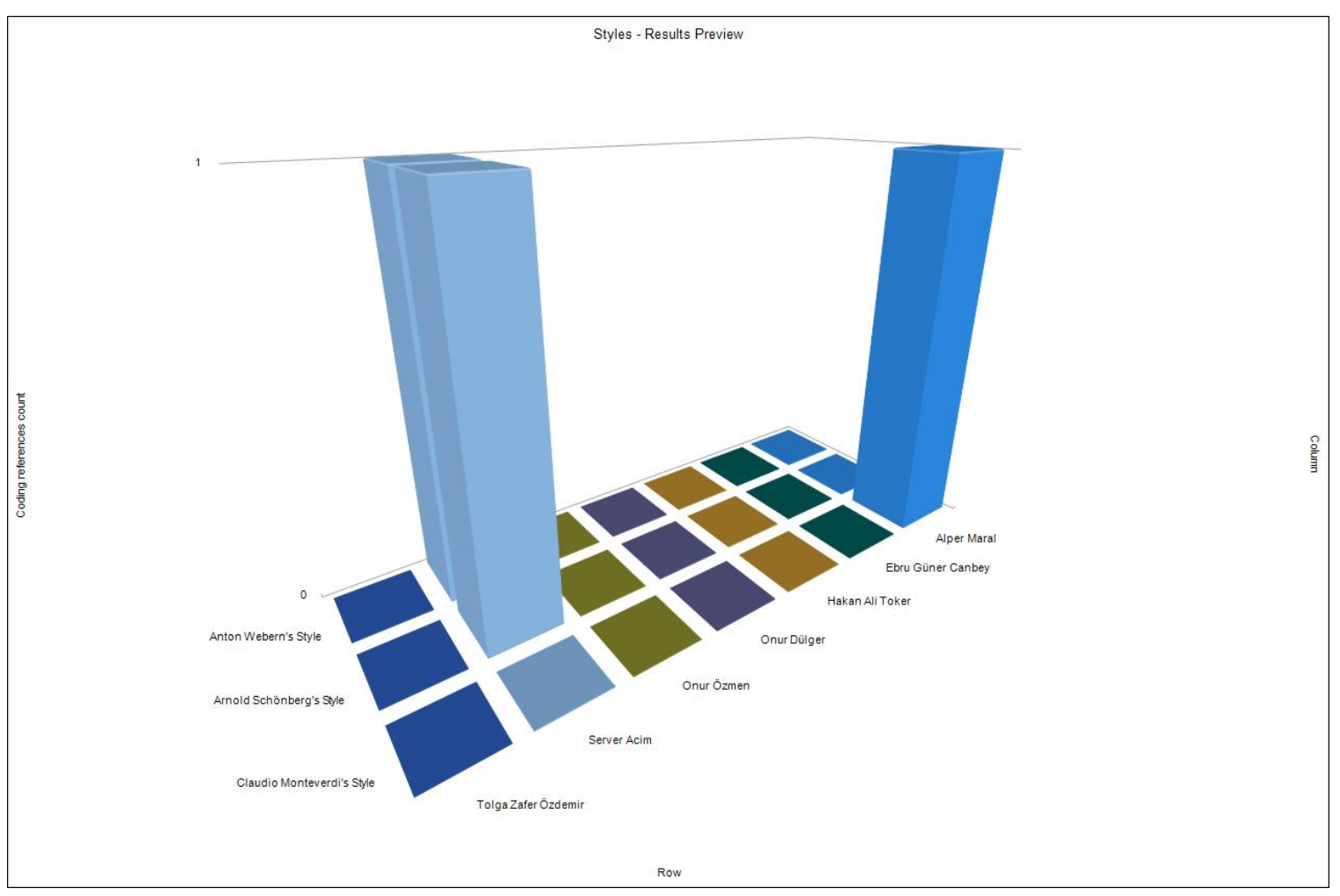

Figure 5. Styles

The identified codes and composer answers are presented below:

\subsubsection{Claudio Monteverdi Style}

With this style, the condition of composers to be influenced by Claudio Monteverdi Style while they are producing their solo piano pieces and other pieces was assessed. Monteverdi's composition understanding is as follows:

Claudio Monteverdi (1567-1643) who is regarded as one of the milestones of the music history passed into history as a creator who had started the Baroque Era in the field of music and highlighted harmonic writing... Melodic domination and vertical polyphony (harmonic frame) had become prominent. The improvement of "Tonality" understanding got strength from the art of opera as well. (Say, 2010a).

One composer shared an opinion on this code.

... Of course, there are composers who I find close to myself and take as an example ... Such as Claudio Monteverdi... (Alper Maral, interview: 29/03/2017).

\subsubsection{Anton Webern Style}

With this code, the condition of composers to be influenced by Anton Webern Style while they are producing their solo piano pieces and other pieces was assessed. The composer was defined by Say as: "Anton Webern (1883-1945) who had an extraordinarily plain language and wrote short pieces is a composer whose pieces are frequently performed. With the definition of Schönberg 'It can be understood how prudent the expression of Webern who wrote a novel in one page" (Say, 2010a).

One composer shared an opinion on this code.

From time to time we hear some parts of the music, let's say through 10 measure or 12 measure, like in a manner of "Twelve Tone" technique ... We hear 12 measure in a structure that is similar to Anton Webern music (Server Acim, interview: 18/03/2017).

\subsubsection{Arnold Schönberg Style}

With this code, the condition of composers to be influenced by Arnold Schönberg Style while they are producing their solo piano pieces and other pieces was assessed. The composer was defined by Say as: "Arnold Schönberg (1874-1951) replaced tonal harmony with a new order and developed the "12 Notation System" that methodize 
non-tonal music writing." (Sachs, 1965, s. 243 as cited in Say, 2010a).

The composer opinion on this code is given below.

From time to time we hear some parts of the music, let's say through 10 measure or 12 measure, like in a manner of "Twelve Tone" technique ... We hear 12 measure in a structure that is similar to Arnold Schönberg music (Server Acim, interview: 18/03/2017).

\subsection{Techniques}

With this theme, the techniques of the composers have been influenced while they are producing their solo piano pieces and other pieces of art. This theme was constituted with 5 codes in the direction of the composer's opinions. The analysis of the theme that was conducted by NVivo11 program is given below.

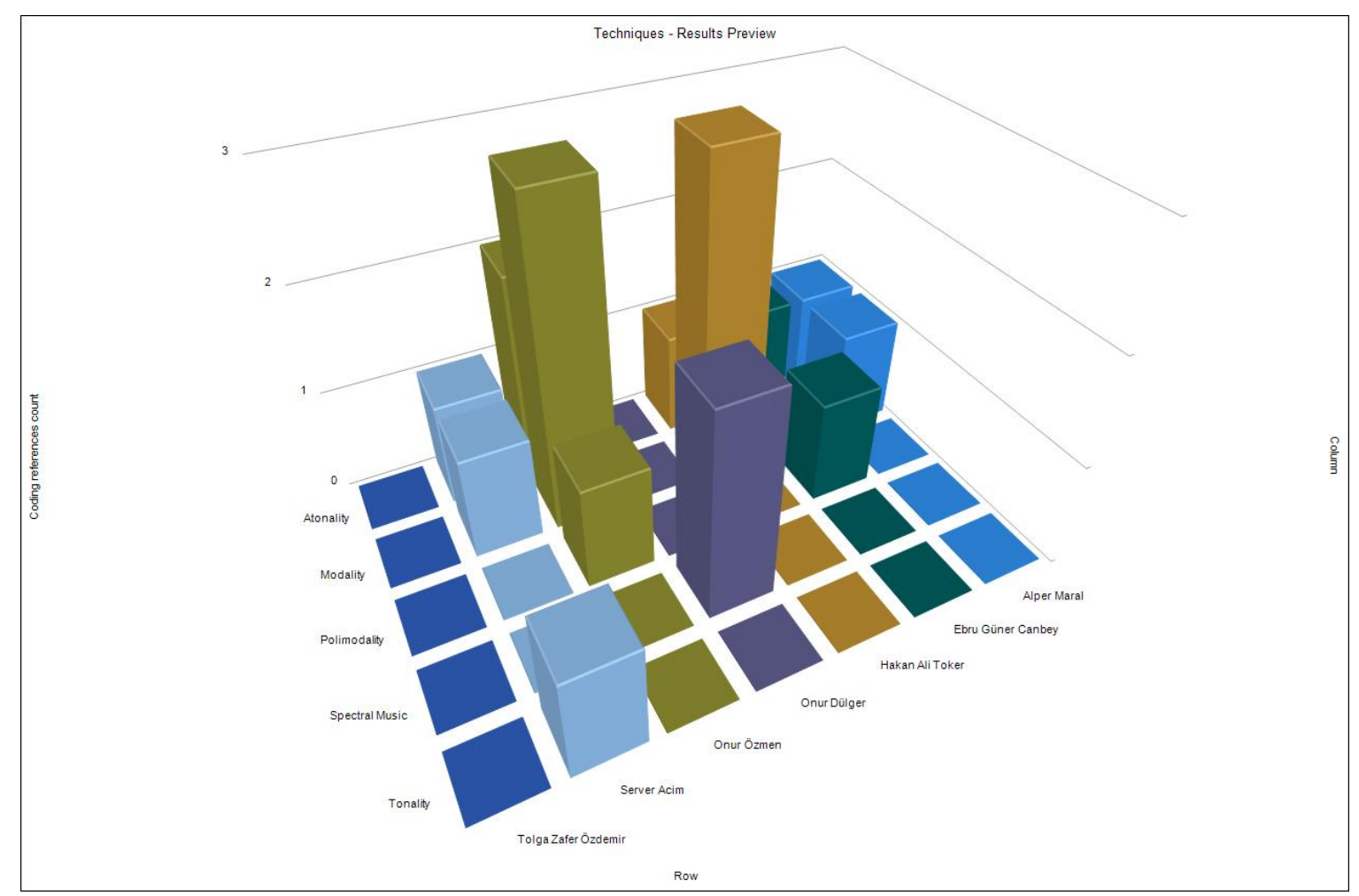

Figure 6. Techniques

The codes and opinions of the composers are presented below.

\subsubsection{Tonality}

With this code, the condition of composers to use the tonality technique while they are producing their solo piano pieces and other pieces was assessed. The explanation of tonality is as follows. "Tonality is determined in a serial with a tonic sound with a feature that pulls all the other sounds towards to itself. The presence of a work in the tone of Do Major or Re minor means the tonal center in that work is the sound of Do or Re." (Say, 2009).

The composer opinion on this technique is given below.

... Not the entire piece... tonal effects can resound in some parts but not in the entire piece... (Server Acim, interview: 18/03/2017).

\subsubsection{Atonality}

Under this title, atonality that is a composition technique which is used by composers in their solo piano pieces and other pieces was assessed. This current was defined by Say as follows: The current which has emerged as a result of the reflection of Expressionism on the art of music (Cangal, 2014). It is the comprehension which is out of the tonality, the system of tonal harmony. Atonal music means to not requiring tonal chord and diatonic harmonies which are related to that functionally... (Say, 2009). 
According to that composer's opinions are as follows:

... that is to say I ground on a more independent edition starting from actual sounds and sound patterns instead of using the issues as tonality, pantonality, atonality, and modality (Alper Maral, interview: 29/03/2017).

... Atonality (Ebru Güner Canbey, interview: 17-31/03/2017).

... there are many pieces which were written with the impressionist, free atonal or 12-tone system... (Hakan Ali Toker, interview: 04-12/03/2017).

... Indeed Op. 2298 is a music that I used free atonality and enigmatic serial in the middle and the music that I can describe as under the influence of Stravinsky in terms of colors... (Onur Özmen, interview: 16/03/2017).

... In my pieces... Let's say we hear 12 measures in a structure that is similar to Schönberg, Anton Webern, Alban Berg music and in the manner of 12 Tone technique... (Server Acim, interview: 18/03/2017).

\subsubsection{Modality}

With this code the condition of composers to use the concept, "modality" while they are producing their solo piano pieces and other pieces was assessed. The explanation of modality is as follows. "Modality is the system of music that employs modes. The quality is determined according to the mode" (Say, 2009).

In accordance with the question asked to the composers, it is seen that they benefit from modes.

... I have been interested in all of them... tonality pantonality, atonality, and modality (Alper Maral, interview: 29/03/ 2017).

... I use Turkish folk music pitches, feet, measures which are aksak and non-aksak, sentence structure and ornamentation if I think it is needed while I am composing (Hakan Ali Toker, interview: 04-12/03/2017).

... "7 Miniature" was a piece of art that included inspirations from our Turkish music, Turkish folk music but as I say it was composed inventively in a "makamsal" (maqam) dimension. Which we can state as 7 small brushstrokes or 7 small "haiku" (Onur Özmen, interview: 16/03/2017).

... I use the series of Turkish classical music as the baseline (Server Acim, interview: 18/03/2017).

\subsubsection{Polymodality}

With this code, the condition of composers to use the polymodality as a technique in the process of composing their solo piano pieces and other pieces was assessed. The explanation of polymodality is as follows. Polymodality is defined as "Multi-modality. The use of more than one modes simultaneously (Starting from polytonality)." (Dolgun, 2008). “... When different modes are announced in different tone centers simultaneously, such kind of a passage is both polymodal and polytonal..." (Persichetti, 1961 as cited in Dolgun, 2008).

In this direction, two composers shared their opinions on polymodality among the techniques they use.

... Polymodality (Ebru Güner Canbey, interview: 17-31/03/2017).

... The last piece of it was a dodecaphonic, short, small piece. I called it 10 Little Pursuits". Because there are a lot of techniques... polymodal, new contrapuntal used by Bartok, certain imbricative structures an Muammer Sun style stuff (Onur Özmen, interview: 16/03/2017).

\subsubsection{Spektral Music}

With this code, the condition of composers to use the "Spectral Music" as a technique in the process of composing their solo piano pieces and other pieces was assessed.

Spektral Music or spectralism is a composition technique that was developed in the 1970s that improves the quality of the tone of acoustic music or the artificial resonances obtained from synthesis by using computer analysis. Spektral Music that is defined in the technical language is an acoustic music practice that the composition decisions are mostly stated by sonographic projections and mathematical analysis of sound spectrums or with spectrums that are formed mathematically...The term, spectral music was written by Hugues Dufourt in 1979 and produced in an article that was published for the first time after two years (Spektral Müzik, Date of Access: 06. 06. 2017).

In this direction one composer shared an opinion. The opinion of the composer is as follows:

New complexity and Spectral music are currents that I am interested in and impress me... (Onur Dülger, interview: 24/03/2017, 30/09/2017). 


\subsection{Genres}

With this theme, the genres of the composers have been influenced while they are producing their solo piano pieces and other pieces of art. This theme was constituted with 9 codes in the direction of the composer's opinions.

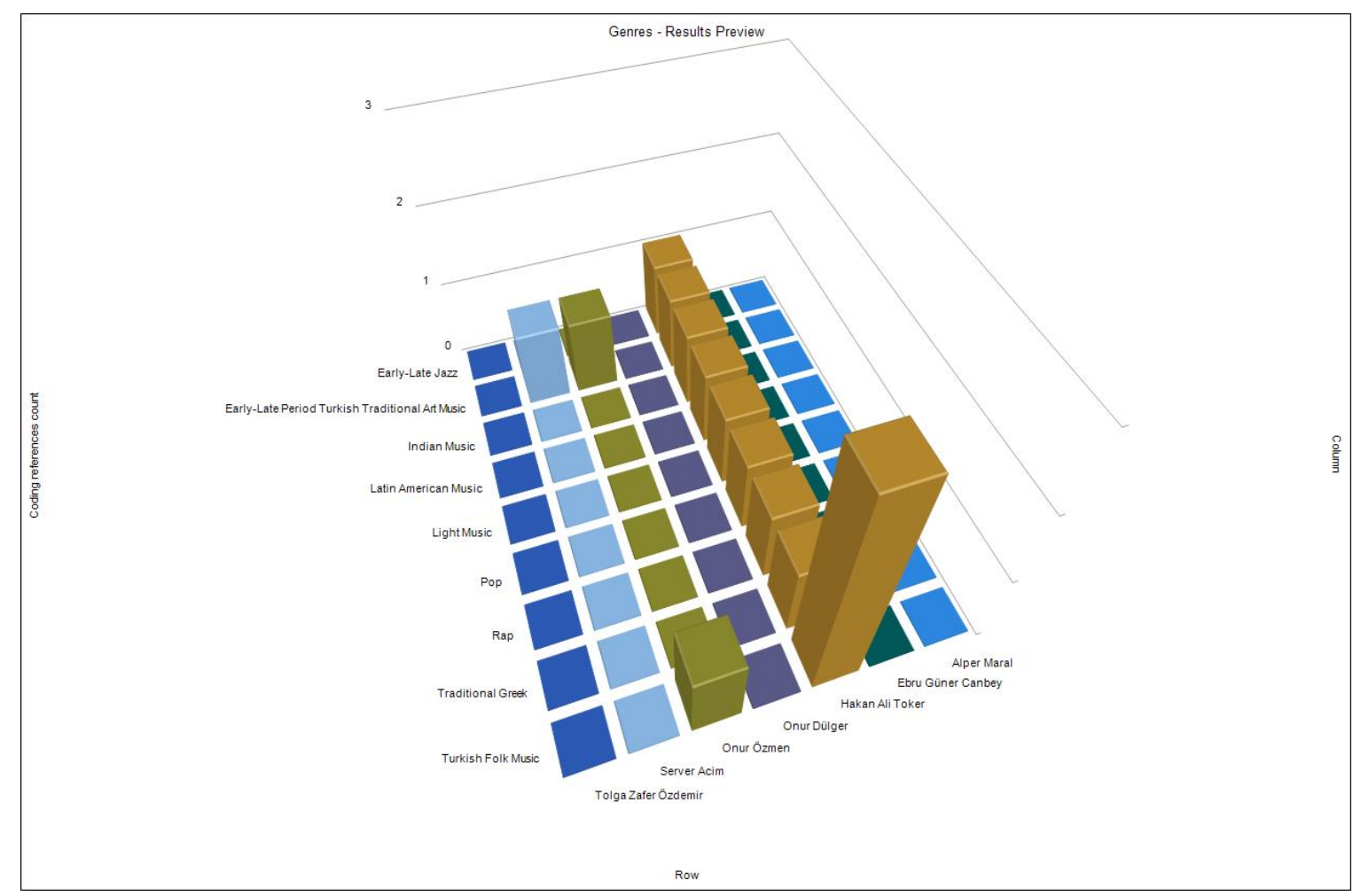

Figure 7. Genres

The codes and opinions of the composers are given below.

\subsubsection{Early-Late Period of Jazz}

With this code, the condition of composers to use the "Jazz Music" while they are composing their solo piano pieces and other pieces was assessed. Say defined this style as follows:

The genre of popular music which is one of the main factors on the 20th-century music with its musical quality and development path... African music among the components of jazz synthesis that is created by the conjunction of African-European based rhythm and melody, European harmony and instruments ... At the end of the 19th century, it has gained a new flavor with "Blues" that was turned into very effective equipment (Say, 2009).

The composer and his opinion on this style are given below.

Among the techniques that I have examined and used in my works, I have also used early and late period jazz music, apart from the 20th-century techniques that I listed above (Hakan Ali Toker, interview: 04-12/03/2017).

\subsubsection{Latin America}

With this code, the condition of composers to use the "Latin American Music" while they are composing their solo piano pieces and other pieces was assessed. Say defined this style as follows: "Traditional music of the people who live in Central and South America, Mexico and Caribbean countries. The traditional music of Latin American countries displays a synthesis that Iberia- Africa-origin ethnic groups have contributed with centuries." (Say, 2009).

One composer shared an opinion on this genre.

Among the techniques that I have examined and used in my works, I have also used Latin American Music, apart from the 20th-century techniques that I listed above (Hakan Ali Toker, interview: 04-12/03/2017). 


\subsubsection{Traditional Greek Music}

With this code, the condition of composers to use the "Traditional Greek Music" while they are composing their solo piano pieces and other pieces was assessed. This style was defined as follows:

The Greek music which was mainly active between the 8th century B.C. and 2nd century B.C. is a music that is generally performed with or without instrumental accompaniment ... The Ancient Greek music which is profoundly developed had shown a development interrelated manner in the fields of modes, rhythms and notation system (Say, 2010a).

One composer shared an opinion on this genre.

Among the techniques that I have examined and used in my works, I have also used Ancient Greek styles, apart from the 20th-century techniques that I listed above (Hakan Ali Toker, interview: 04-12/03/2017).

\subsubsection{Indian Music}

With this code, the condition of composers to use the "Indian Music" while they are composing their solo piano pieces and other pieces was assessed. This style was defined as follows:

... Indians separate music into 3 groups: Sound music, instrumental music and dance. The sound music is called "gana", instrumental music is called "vadya" and dance music is called "nitriya". In the traditional Indian music the pitches of voice that constitute the serials and characterized according to the Sanskrit alphabet are as follows: Sa, Ri, Ga, Ma, Pa, Dha, Ni. However certain pitches include intervals with "koma" called "Sruti" which are smaller than a half pitch. The notation has been also developed by using the names of the letters (Say, 2009).

The composer who shared an opinion on this style is given below.

Among the techniques that I have examined and used in my works, I have also used Indian styles, apart from the 20th-century techniques that I listed above (Hakan Ali Toker, interview: 04-12/03/2017).

3.5.5 Early-Late Period Turkish Traditional Art Music

With this code, the condition of composers to use the "Traditional Turkish Classical Music" while they are composing their solo piano pieces and other pieces was assessed. This style was explained as follows:

... It is also defined by titles as "Divan Music", "Classical Turkish Music". Our traditional classic music has two parts as religious and non-religious... In Turkish Classical music the sounds do not arise from the whole and half pitches as in the Western music but from pitches that are constituted by smaller intervals called comma... The seventeen-pitch system is employed as in our folk music... Rhythm patterns are named "usul"... In terms of verbal components, the styles of Ottoman (Divan) poetry were employed mostly... The composer treats his/her artistic creativity within this network of rules (Say, 2010a).

The composer opinions on this style are presented below.

... I have used the styles of early and late period Turkish classical music and Turkish folk music (Hakan Ali Toker, interview: 04-12/03/2017).

... I worked on a style which is based on resonance related pursuits and isolating the spices of our maqams in the works that I composed for piano (Onur Özmen, interview: 16/03/2017).

I use the series of Turkish classical music as the baseline (Server Acim, interview: 18/03/2017).

\subsubsection{Turkish Folk Music}

With this code, the condition of composers to be influenced by the "Traditional Turkish Folk Music" while they are composing their solo piano pieces and other pieces was assessed. This style was describes by Say as follows:

The genre of music that expresses the feelings and thoughts of our people by forming its long-established tradition within the history. It has rural origins. The main characteristics of the folk music are: being modal (makamsal), anonymous and non-religious. In all of its style the pitch system of the rational Turkish music is employed... Our folk music melodies are in a sound space that covers a one and a half octave scale. The sorts vary according to the region. The modal (makamsal) roots are called "feet". On the other hand, the rhythms of the folk music are not given specific names as in traditional classical music. The musical terms vary according to regions (Say, 2009).

The composer opinions concerning the aforementioned code are given below. 
I use Turkish folk music pitches, feet, measures which are aksak and non-aksak, sentence structure and ornamentation if I think it is needed while I am composing. Yes, as I have just stated above, I consider our culture as a rich resource from many different aspects ... there are many pieces with and without national characteristic ... I have used Turkish folk music, mystic music...styles (Hakan Ali Toker, interview: 04-12/03/2017).

"7 Miniature" was a piece of art that included inspirations from our Turkish music, Turkish folk music but as I say it was composed inventively in a modal (makamsal) dimension. Which we can state as 7 small brushstrokes or 7 small "haiku" (Onur Özmen, interview: 16/03/2017).

\subsubsection{Light Music}

With this code, the condition of composers to be influenced by the "Light Music" while they are composing their solo piano pieces and other pieces was assessed. The definition of light music is as follows:

The concept is used by our society to define popular music inappropriately. When "Light Music" is used in a way to express "music without an artistic weight" it may lead to confusion; because popular music or music towards entertainment also hold an artistic value in a certain extent. It is not possible to think about a music genre without an artistic value" (Say, 2010b).

In this direction, one composer shared an opinion.

...I have also used Light Music styles... (Hakan Ali Toker, interview: 04-12/03/2017).

\subsubsection{Pop}

With this code, the condition of composers to be influenced by the "Pop Music" while they are composing their solo piano pieces and other pieces was assessed. This genre of music is defined as follows: "The genre of music which is adopted by masses and described by the abbreviation of the word "popular" which means "widespread"... In terms of the meaning, the term describes "entertainment music" (Say, 2009).

One composer shared an opinion on this style.

... I have also used Pop Music styles... (Hakan Ali Toker, interview: 04-12/03/2017).

\subsubsection{Rap}

With this code, the condition of composers to be influenced from the "Rap" while they are composing their solo piano pieces and other pieces was assessed. The definition of the genre, Rap, is as follows: "The sort of pop music that has been initiated by disk jockeys from New York in the middle of the 1970s that is revived up with eye-pleasing feet-percussion dance currents in addition to the monotonic rhythmic talks." (Say, 2010b).

In this direction, one composer shared an opinion.

...I have also used rap styles... (Hakan Ali Toker, interview: 04-12/03/2017).

\section{Discussion}

In this section, the findings obtained regarding the research problem were discussed. The codes, currents, composers, styles, techniques and genres were obtained through the question that was asked to the composers"Which musical currents and styles that are called as "new music" in the piano literature do you adopt?"- were formed as themes and the opinions were assessed in this direction. Among these themes, the ones with the highest frequency are "Currents" and "Techniques" with six frequencies (Figure 2). The currents that the composers influenced are impressionism, electronic music, Instrumental Concrete Music (Musique Concréte Instrumentale), new complexity, new classism, new romanticism, minimalism, serialism), Fluxus and pluralism. Among the themes, the one with the highest frequency was the code "Pluralism" and has 5 frequencies (Figure 3).

The composers that the composers were influenced from in their solo piano pieces and other pieces are İlhan Mimaroğlu, İgor Stravinsky, Alban Berg, Karlheinz Stockhausen and Guillaume de Machaut. Within this code, each composer has a frequency and no specific name of a composer with a higher frequency could be obtained (Figure 4). The styles that the composers were influenced from are Claudio Monteverdi Style, Anton Webern Style and Arnold Schönberg Style (Figure 5). Yöre explained the distinctive feature of the "Style" code as follows: “... it is a concept that determines the idiosyncratic creation in art. In other words, despite the fact that an artist is involved in a current, she or he has a unique style of creation. That is a feature that presents the authenticity of that artist (Yöre, 2011). In this direction, the difference between the code "composers" that the composers were influenced form in their solo piano pieces and other pieces and the code "styles".

The techniques that composers use in their solo piano pieces and other pieces were identified as tonality, atonality, modality, polymodality, and spectral music. Among these techniques, the code" atonality" which has 5 frequencies 
were identified as the code with the highest frequency (Figure 6). At the same time, the genres that the composers are influenced were identified as; early-late period jazz, early-late period Turkish classical music, traditional Greek music, light music, Indian music, Latin American music, Pop, Rap, Turkish Folk Music. With this code "Early-Late Period Turkish Classical Music" that has 3 frequencies was defined as the code with the highest frequency and in addition to that Turkish Folk Music ranks number two with 2 frequencies (Figure 7).

Under the theme "currents", it is seen that the currents that the present-day Turkish composers influenced or used in their piano pieces are in the time interval that start from the 19th century until today. In addition to that "Pluralism" that has the highest frequency demonstrates that the composers do not adhere to a single philosophy. It is thought that this code is an inevitable result of the multi-cultural environment that enhances the creativity of the composers (Toksoy, 2014).

In the theme "Styles" that influence the piano literature, the composer who left a mark on the music history were addressed. It is seen that the composers who influence the present-day Turkish composers lived in the 1300s, 19th, 20th and 21 st centuries. It is seen that while it was prevalent to influence from the previous century in the sense of art until the 20th century, today the pace of reaching information has enabled our composers to benefit from the resources that almost trace back 700 years ago. This situation assists us to form an opinion on in what extent the currents will be shaped.

It is seen that the three composers that present-day Turkish composers in terms of "style" are from the Baroque and Contemporary Period. It is also seen that the components-individuals that are obtained in the framework of "composers" and "styles" cover the 1300s, Baroque Period, Post-Romantics, 20th Century music and present-day 21th-century music; no findings concerning the 18th Century Classical Period can be found.

Starting from the codes "genres", it is seen that composers are influenced from the national and international musical genres; and among these genres, local music and folk music play an important role. On the other hand, it is seen that the aforementioned local music and folk music do not only belong to the geography of the composers or similar regions and the music genres that trace back to B.C. 3000 (such as Indian Music) are mentioned. In addition to that other codes that are included in the theme cover popular music genres; and this situation becomes the indicator of the cultural globalization. Bulut (2007) supports this idea by mentioning in the master's thesis that composers are influenced by both different music genres and composers.

Again, the codes "Turkish Folk Music" and "Early-Late Period Turkish Classical Music" which are included in the same theme demonstrate the condition of composers to be influenced from the geography that they belong. "... When it is considered from this perspective it can be said that there a various acts of the contemporary Turkish composer in terms of handling the materials. As it should be, the composer will appear with a "new" expression as a result of the conditioning of the culture that is integrated with him." (Doğuduyal, 2016).

When the codes that are included in the theme "Techniques" which was created with the question asked to the composers are considered, the codes that are used in producing the piano literature melodically and harmonically were addressed. At this point, it can be seen that the codes such as "Spectral Music" that affects music as a result of melodic structures (modality-polymodality), atonality that has emerged in the 20th Century and the changes in the technology in the 21 st century in addition to tonality. At this juncture, it is thought that the concepts of "modality" and "polymodality" are the results of the national and international folk music and traditional-local music which are included in the previous theme, "genres". Because traditional music includes different modal structures apart from the ordinary tonal structures, the codes are regarded as interrelated and even a result of each other.

Again, the code "atonality" which belongs to this code is interrelated with the code "Alban Berg" from the theme "composers", the codes "Arnold Schönberg" and "Anton Webern" from the theme "styles". The three pioneers of the atonal music are Arnold Schönberg (1874-1951), Alban Berg (1885-1935) and Anton Webern (1883-1945)." (Say, 2009).

It is seen that the codes "Spectral Music" and "Electronic Music" and "Instrumental Concrete Music" that are included in the theme "Techniques" are complementary codes. These codes reveal how the developing technology is integrated in the aesthetic understanding. Beşevli-Solmaz (2010) supports this situation by mentioning that the new pursuit of resonance has been actualized with the use of technology. Bora explained this situation as follows: "Today, innovations are presented by means of the producing methods of composers, the use of technology in line with the developments in the science and the impact of computer and digital sound technology on music production... new orientations in the new music and its requirements have provided new motivations to science and technology in terms of creating solutions" (Bora, 2010).

In addition to that, the aforementioned codes and the code "Karlheinz Stockhausen" code which belongs to the 
theme "composers" are related. "Stockhausen who put an effort to associate electronic music with a musical method in the years of 1965-1966 had inclined to express the "essence of the matter in the universe" (Say, 2010a).

Another component that Karlheinz Stockhausen is related with is the code "Fluxus" which belongs to the theme "currents". Stockhausen is regarded as one of the most important composers of this current (Atakan, 2015).

The organic ties of these similar codes that were obtained from the 7 composers have emerged. In addition to that, the non-similar codes demonstrate that how composing material can be diversified. These data present to the audience, performers and the young prospective composers an example of how various materials can be extended in order to enable them to make sense of the music of today.

Today the variety in the understanding of aesthetics, the wide range of opportunities provided for composers by different folk music, world music, the developments in transportation and technology and different philosophical understandings and it is seen that composers are influenced from these factors by being aware of it or instinctively or that they use these elements. It is thought that this study conducted with the purpose of understanding the composition of the elements in the solo piano works by addressing today's music and opinions of the composers will make a positive contribution to the piano and music educators and the students who have studied academic piano education.

\section{References}

Akbulut Demirci, Ş. (2010). The use of extended piano techniques at conservatories in Turkey. Procedia Socialand Behavioral Sciences, 2(2), 3080-3087. https://doi.org/10.1016/j.sbspro.2010.03.469

Akbulut Demirci, Ş., \& Savaş, M. (2012). Extended piano techiques and two pieces. International Journal of New Trends in Arts, Sports \& Science Education, 1(3), 1-9.

Aktüze, İ. (2003). Müziği anlamak: Ansiklopedik müzik sözlüğü. İstanbul: Pan Yayınc1lık.

Atakan, N. (2015). Sanatta alternatif arayışlar. İzmir: Karakalem Kitabevi Yayınları.

Barney, D. C., \& Pleban, F. T. (2018). An examination of physical education teachers' perceptions of utilizing contemporary music in the classroom environment: A qualitative approach. The Physical Educator, 75, 195-209. https://doi.org/10.18666/TPE-2018-V75-I2-7447

Beşevli-Solmaz, P. (2009). Bülent Arel ve 1960 sonrasında çağdaş müzikte anlam arayışları (Beş viol ve teyp için fantezi ve dans üzerine bir yorum denemesi). In P. Susanni, \& U. Bora (Eds.), İzmir Ulusal Müzik Sетроzуити 5-6 Kasım 2009 (ss. 68-89). İzmir.

Bora, U. (2009). Müzikte İnsan-Makine Etkileşmi Sergileyen Bir Algoritmik Kompozisyon Örneği "Piyano Fantezisi”. In P. Susanni, \& U. Bora (Eds.), İzmir Ulusal Müzik Sempozyumu 5-6 Kasım 2009 (ss. 90-97). İzmir.

Bulut, M. Ö. (2007). Genç Türk bestecilerinin eser yaratma süreçlerinde kullandıkları ritimsel elemanlar (Master's thesis).

Cangal, N. (2014). Armoni. Ankara: Arkadaş Yayınevi.

Çepni, S. (2012). Araştırma ve proje çalışmalarına giriş. Trabzon: Celepler Matbaacıllk.

Choi, E., \& Keith, L. J. (2016). Culturaldiversity: Resources for music educators in selected works of three contemporary African-American classical composers. Music Educators Journal, 103(2), 35-40. https://doi.org/10.1177/0027432116670459

Coulembier, K. (2016). Multi-temporality: An analytical approach to contemporary music, embracing concepts of Gilles Deleuze and Félix Guattari. Music Analysis, 35(3), 341-372. https://doi.org/10.1111/musa.12074

Creswell, J. W. (2013). Nitel araştırma yöntemleri beş yaklaşıma göre nitel araştırma ve araştırma deseni (M. Bütün \& S. B. Demir, Trans.). Ankara: Siyasal Kitabevi.

Danziger, R. (1991). The revelation of music: Learning to love the classics. New Haven: JordonPress.

Demirel, E. (2015). Çağdaş Türk bestecilerinde postmodern bir eğilim olarak yeniden yerellik. E-Journal of New World Sciences Academy, 10(2), 84-99. https://doi.org/10.12739/NWSA.2015.10.2.ICO634

Doğuduyal, M. (2016). Müzikten söze. İstanbul: Bağlam Yayıncılık.

Dolgun, A. (2008). Necil Kâzım Akses'in Birinci Yaylı Çalgılar Dörtlüsü'nün polimodal ve politonal açılardan incelenmesi (DMA Dissertation). Retrieved from http://docplayer.biz.tr/17942593-Necil-kazim-akses-inbirinci-yayli-calgilar-dortlusu-nun-polimodal-ve-politonal-acilardan-incelenmesi.html 
Ece, A. S. (2002). The viola works of contemporary Turkish composers and the situation of recognition of these works and whether these works are used for educational purposes or not by the viola instructors in institutions that give Professional music education. G. Ü. Gazi Eğitim Fakültesi Dergisi, 22(3), 93-107.

Ece, A. S. (2006). 1904-2004 yılları arasında çağdaş Türk bestecilerinin biyografik özellikleri ve eğitim süreçleri. Abant İzzet Baysal University Eğitim Fakültesi Dergisi Güzel Sanatlar Özel Sayısı (pp. 28-41).

Feridunoğlu, L. (2004). Müziğe giden yol: Genç müzisyenin el kitabı. İstanbul: İnkılâp Kitabevi Yayın Sanayi ve Ticaret A.Ş.

İlyasoğlu, E. (2007). 71 Türk bestecisi: 71 Turkishcomposers. İstanbul: Pan Yayıncılık.

Kennedy, M. (1996). Oxford dictionary of music (4th ed.). UK: Oxford University Press.

Lachenmann, H. (1970). Lachenmann: Pression. Retrieved from http://www.breitkopf.com/feature/werk/1129

Leech, N. L., \& Onwuegbuzie, A. J. (2007). An array of qualitative data analysis tools: A call for data analysis triangulation. School Psychology Quarterly, 22(4), 557-584. https://doi.org/10.1037/1045-3830.22.4.557

McAndrew, S., \& Everett, M. (2014). Music as collective invention: A social network analysis of composers. Cultural Soclology, 9(1), 56-80. https://doi.org/10.1177/1749975514542486

Mimaroğlu, İ. (1990). Müzik tarihi. İstanbul: Varlık Yayınları.

Nayir, A. E. (2017). Fazıl Say’ın “İstanbul Senfonisi”nde geleneksel ve çağdaş türk müziği unsurlarının incelenmesi. Abant İzet Baysal University Eğitim Fakültesi Dergisi, 17(4), 2046-2057. https://doi.org/10.17240/aibuefd.2017.17.32772-363991

New-Romanticism. (June 6, 2017). In Onmusic dictionary. Retrieved from https://dictionary.onmusic.org/terms/2336-new_romanticism

Orning, T. (2012). Pression-A performance study. Music Performance Research, 5, 12-31.

Persichetti, V. (1961). Twentieth century harmony. New York: W.W. Norton \&Company.

Pluralizm. (2017, June 7). In Türk Dil Kurumu. Retrieved from http://www.tdk.gov.tr/index.php?option=com_gts \&arama $=$ gts\&guid=TDK.GTS.5a1d2f50152ce3.63949507

Polat, S., \& Hiçyılmaz, G. (2017). Sınıf öğretmenlerinin maruz kaldıkları ayrımcılık davranışları ve bu davranışların nedenleri. Eğitimde Nitel Araştırmalar Dergisi, 5(2), 47-66. https://doi.org/10.14689/issn.2148-2624.1.5c2s3m

Predoi, P. (2017). Interdisciplinarity: Reference of contemporary music pedagogy. Bulletin of the Transilvania University of Brasov-Special Issue-Series VIII: Performing Arts, 10(59), 263-268.

Sachs, C. (1965). Kısa dünya musikisi tarihi (İ. Usmanbaş Çev.). İstanbul: Milli Eğitim Basımevi. (Eserin orijinali 1949 'da yayımlanmıştır).

Say, A. (2009). Müzik sözlüğü. Ankara: Müzik Ansiklopedisi Yayınları.

Say, A. (2010a). Müzik tarihi. Ankara: Müzik Ansiklopedisi Yayınları.

Say, A. (2010b). Müzik ansiklopedisi. Ankara: Müzik Ansiklopedisi Yayınları.

Sönmezöz, F. (2015). Comparative analysis of the approaches used by prospective music teachers in Turkey in practicing the piano works of contemporary Turkish composers. Educational Research and Reviews, 10(22), 2869-2879. https://doi.org/10.5897/ERR2015.2482

Spektral Müzik. (2017, June 6). In Vikipedi. Retrieved from http://www.wikizero.org/index.php?q= aHR0cHM6Ly9lbi53aWtpcGVkaWEub3JnL3dpa2kvU3BlY3RyYWxfbXVzaWM

Toksoy, A. C. (2014). Çok kültürlü müzik eğitimi. Akademik Bakış Dergisi, 40, 1-28.

Ulman, E. (1994). Some thoughts on the new complexity. Perspectives of New Music, 32(1), 202-206. https://doi.org/10.2307/833163

Yıldırım, A., \& Şimşek, H. (2016). Sosyal bilimlerde nitel araştırma yöntemleri. Ankara: Seçkin Yayıncılık.

Yöre, S. (2012). Temel besteleme malzemeleriyle çağdaş müzik. İstanbul: Bağlam Yayıncılık.

Yöre, S. (2011). Çağdaş müzik: Bestecilik ana akımları, teknikleri ve başlıca besteciler. Ç. Ü. Sosyal Bilimler Enstitüsü Dergisi, 20(3), 1-20. 


\section{Notes}

Note 1. This article is prepared from Eda Nergiz's thesis named "According to the opinions of contemporary Turkish composers the effects of Turkish music on contemporary piano literature and its reflections on professional music education”, in Bursa Uludag University Education Science Institution, in 2017.

Note 2. Expressions that appear as "child" in the themes and code maps represent sub-codes in the NVivo 11 Qualitative Data Analysis Program.

\section{Copyrights}

Copyright for this article is retained by the author(s), with first publication rights granted to the journal.

This is an open-access article distributed under the terms and conditions of the Creative Commons Attribution license (http://creativecommons.org/licenses/by/4.0/). 